\title{
The Use of Project Method in Teaching Arts
}

\section{-An Interdisciplinary the Use of Project Method in Teaching Arts, An Interdisciplinary Approach in High School}

\author{
Kampouropoulou Maria ${ }^{1}$ \\ ${ }^{1}$ Department of Primary Education, University of the Aegean, Rhodes, Greece \\ Correspondence: Maria Kampouropoulou, University of the Aegean, Department of Primary Education, Rhodes, \\ Greece. Tel: 30-224-109-9250. E-mail: kampour@rhodes.aegean.gr
}

$\begin{array}{lr}\text { Received: February 21, } 2015 & \text { Accepted: May 13, } 2015 \quad \text { Online Published: July 24, } 2015 \\ \text { doi:10.5539/res.v7n11p159 } & \text { URL: http://dx.doi.org/10.5539/res.v7n11p159 }\end{array}$

\begin{abstract}
The research refers to the use of project method by High School students who were attending the third grade of High School in Rhodes, Greece. We did an investigation in order to determine the improvement of students' attitudes and views towards the subject of Arts using the project method. The teaching intervention had interdisciplinary characteristics and the subject of the project was "the acropolis of Filerimos". Questionnaires were given to the students before and after the teaching intervention which was implemented during the first quarter of the school year 2014-2015. The results showed that the use of project method vindicated the goal of the study and improved significantly the students' views and attitudes towards the subject of Arts.
\end{abstract}

Keywords: Arts, project method, interdisciplinary teaching

\section{Introduction}

In contrary with the traditional educational models that are based on the cleavage of knowledge, the interdisciplinary teaching focuses on a holistic view of the conquest of new knowledge using a multifaceted approach of teaching. Students gather the knowledge from various subjects, examine critically the different sides of an issue and reach new experience in a comprehensive process. The implementation of the project method is an important axis of the cross-thematic teaching practice (Johnson \& Johnson, 1994). The school projects include a series of teaching activities and methodological approaches. For example a group of teachers and students decides to deal with a specific topic, plans its own program of actions, and handles the plan until the end of the project (Starko, 1995; Kampouropoulou et al., 2013). Result of this collective work can be the publication of a book, an event, a report, an exhibition, etc. The beginning of carrying out a project may be a suggestion of a teacher or a student. All members need to comment their proposals and agree on a final form of the project and contribute to the conduct of the work. These three processes, namely the freedom of members to suggest a topic, the joint configuration and its realization, are the basic characteristics of a creative project and, if it is realized properly, the teaching experience acquired by students is a significant source of learning (Kampouropoulou et al., 2012).

The subject of Arts finds fertile ground in interdisciplinary approach of knowledge. By applying the appropriate interdisciplinary project with Arts as the main thematic axis, the emphasis on traditional teaching methodology is reduced and the students' attention shifts to concepts and processes encountered in their real lives (Scott, 1990).

\section{The Didactical Intervention}

During the first quarter of the school year (2014-2015) a research was conducted with the participation of 90 students who were attending the third grade of High School in Rhodes, Greece. The main research question was "Acquiring positive attitudes of students towards the subject of Arts through the use of project method". The theme of the project that was implemented was "the acropolis of Filerimos", which was approached using the subject of Arts as the main interdisciplinary axis of the teaching intervention (Kampouropoulou et al., 2011).

During this project, students:

- Visited the acropolis of Filerimos in the city of Ialysos of Rhodes and areas related to history and cultural 
heritage.

- Studied data related to the culture of Ialysos (Scott, 1990).

- Inspired by historical and social issues and they created their own artistic works related to the acropolis of Filerimos.

- Studied sizes and proportions and they used them in their works.

- Used geometric instruments.

- Presented their work in exhibition held in their school.

The project was realized in an interdisciplinary way and apart from the subject of Arts were served aims and objectives related to the subjects of Language, Computing and Mathematics.

From the perspective of Language: Students developed their linguistic ability, studied texts and sources, wrote and presented their work, organized texts, communicated with each other and with the wider community.

From the perspective of Computing: Students searched the internet for information related to the history and culture of the Filerimos, used Microsoft Word to write their work, chatted via Skype with children residing in Ialyssos in order to collect data from their daily life, presented their work using PowerPoint and multimedia.

From the perspective of Mathematics: Students worked on measurements of areas and volumes, designed shapes and surfaces, used geometric instruments, developed their observation and they used proportions and scales (Isaksen et al., 1994).

\section{The Investigation of the Results}

52 boys $(57.78 \%)$ and 38 girls $(42.22 \%)$, who were attending the third class of the High School, participated in the research during the school year 2014-2015. The research investigated the change of students' views and attitudes towards the subject of Arts after the use of the project method (Torrance, 1962). The children answered a questionnaire before and after the teaching intervention. The questionnaire included items in which students were asked to answer using the five-point scale: strongly disagree, disagree neither agree nor disagree, agree, strongly agree. The items referred to students' views and attitudes towards the subject of Arts and were the same in both questionnaires. We used the paired samples t-test in order to determine whether there is a significant difference between the students' attitudes and views towards the subject of Arts before and after the teaching intervention with the use of the project method. Results of t-test less than 0.05 show that there is a significant difference between the two measurements (Oliver, 2000; Stefos et al., 2011). In order to extract the results of the research, we used the statistical software SPSS v.20 offered by the School of Humanities of the University of the Aegean. The results below show the change of students' opinions. The results per item are presented in the order they appeared in both questionnaires before and after the project.

To the item "I like the subject of Arts" no student answered "Strongly disagree" before and after the project. $26.67 \%$ of the students answered "Disagree" before the project while no student answered "Disagree" after the project. $46.67 \%$ of the students answered "Neither agree nor disagree" before the project while $15.56 \%$ answered "Neither agree nor disagree" after the project. $17.78 \%$ of the students answered "Agree" before the project while $57.78 \%$ answered "Agree" after the project. $8.89 \%$ of the students answered "Strongly agree" before the project while $26.67 \%$ answered "Strongly agree" after the project. The result of t-test is 0.000 which shows that there is a significant difference between the beginning and the end of the teaching intervention with the use of the method project.

To the item "I can understand the subject of Arts" no student answered "Strongly disagree" before and after the project. $24.44 \%$ of the students answered "Disagree" before the project while $4.44 \%$ answered "Disagree" after the project. $40.00 \%$ of the students answered "Neither agree nor disagree" before the project while $24.44 \%$ answered "Neither agree nor disagree" after the project. $26.67 \%$ of the students answered "Agree" before the project while $33.33 \%$ answered "Agree" after the project. $8.89 \%$ of the students answered "Strongly agree" before the project while $37.78 \%$ answered "Strongly agree" after the project. The result of t-test is 0.000 which shows that there is a significant difference between the beginning and the end of the teaching intervention with the use of the method project.

To the item "The subject of Arts is significant" $13.33 \%$ of the students answered "Strongly disagree" before the project while $6.67 \%$ of the students answered "Strongly disagree" after the project. $55.56 \%$ of the students answered "Disagree" before the project while $2.22 \%$ answered "Disagree" after the project. $22.22 \%$ of the students answered "Neither agree nor disagree" before the project while $31.11 \%$ answered "Neither agree nor disagree" after the project. $8.89 \%$ of the students answered "Agree" before the project while $44.44 \%$ answered 
"Agree" after the project. No student answered "Strongly agree" before the project while $15.56 \%$ of the students answered "Strongly agree" after the project. The result of t-test is 0.000 which shows that there is a significant difference between the beginning and the end of the teaching intervention with the use of the method project.

To the item "I like the combination of the Arts with the cultural heritage" $6.67 \%$ of the students answered "Strongly disagree" before the project while no student answered "Strongly disagree" after the project. $31.11 \%$ of the students answered "Disagree" before the project while 4.44\% answered "Disagree" after the project. 46.67\% of the students answered "Neither agree nor disagree" before the project while $26.67 \%$ answered "Neither agree nor disagree" after the project. $11.11 \%$ of the students answered "Agree" before the project while $33.33 \%$ answered "Agree" after the project. 4.44\% of the students answered "Strongly agree" before the project while $35.56 \%$ of the students answered "Strongly agree" after the project. The result of t-test is 0.000 which shows that there is a significant difference between the beginning and the end of the teaching intervention with the use of the method project.

To the item "I can learn Arts" $2.22 \%$ of the students answered "Strongly disagree" before and after the project. $11.11 \%$ of the students answered "Disagree" before and after the project. $33.33 \%$ of the students answered "Neither agree nor disagree" before the project while $26.67 \%$ answered "Neither agree nor disagree" after the project. $35.56 \%$ of the students answered "Agree" before the project while $33.33 \%$ answered "Agree" after the project. $17.78 \%$ of the students answered "Strongly agree" before the project while $26.67 \%$ of the students answered "Strongly agree" after the project. The result of t-test is 0.000 which shows that there is a significant difference between the beginning and the end of the teaching intervention with the use of the method project.

To the item "My skills in Arts will help me get a job" $42.22 \%$ of the students answered "Strongly disagree" before the project while $11.11 \%$ of the students answered "Strongly disagree" after the project. $44.44 \%$ of the students answered "Disagree" before the project while 31.11\% answered "Disagree" after the project. 6.67\% of the students answered "Neither agree nor disagree" before the project while $28.89 \%$ answered "Neither agree nor disagree" after the project. $4.44 \%$ of the students answered "Agree" before the project while $20.00 \%$ answered "Agree" after the project. $2.22 \%$ of the students answered "Strongly agree" before the project while $8.89 \%$ of the students answered "Strongly agree" after the project. The result of t-test is 0.000 which shows that there is a significant difference between the beginning and the end of the teaching intervention with the use of the method project.

To the item "I am interested in talking about Art" $28.89 \%$ of the students answered "Strongly disagree" before the project while $6.67 \%$ of the students answered "Strongly disagree" after the project. $42.22 \%$ of the students answered "Disagree" before the project while $40.00 \%$ answered "Disagree" after the project. $28.89 \%$ of the students answered "Neither agree nor disagree" before the project while $35.56 \%$ answered "Neither agree nor disagree" after the project. No student answered "Agree" before the project while $13.33 \%$ of the students answered "Agree" after the project. No student answered "Strongly agree" before the project while $4.44 \%$ of the students answered "Strongly agree" after the project. The result of t-test is 0.000 which shows that there is a significant difference between the beginning and the end of the teaching intervention with the use of the method project.

To the item "I work hard in the subject of Arts" $22.22 \%$ of the students answered "Strongly disagree" before the project while $6.67 \%$ of the students answered "Strongly disagree" after the project. $31.11 \%$ of the students answered "Disagree" before the project while $20.00 \%$ answered "Disagree" after the project. $33.33 \%$ of the students answered "Neither agree nor disagree" before the project while $28.89 \%$ answered "Neither agree nor disagree" after the project. $11.11 \%$ of the students answered "Agree" before the project while $33.33 \%$ of the students answered "Agree" after the project. $2.22 \%$ of the students answered "Strongly agree" before the project while $11.11 \%$ of the students answered "Strongly agree" after the project. The result of t-test is 0.000 which shows that there is a significant difference between the beginning and the end of the teaching intervention with the use of the method project.

To the item "I feel comfortable when I am doing Arts homework" $2.22 \%$ of the students answered "Strongly disagree" before the project while no student answered "Strongly disagree" after the project. $31.11 \%$ of the students answered "Disagree" before the project while 2.22\% answered "Disagree" after the project. $35.56 \%$ of the students answered "Neither agree nor disagree" before the project while $13.33 \%$ answered "Neither agree nor disagree" after the project. $22.22 \%$ of the students answered "Agree" before the project while $31.11 \%$ of the students answered "Agree" after the project. $8.89 \%$ of the students answered "Strongly agree" before the project while $53.33 \%$ of the students answered "Strongly agree" after the project. The result of t-test is 0.000 which shows that there is a significant difference between the beginning and the end of the teaching intervention with 
the use of the method project.

To the item "I can do Arts homework" no student answered "Strongly disagree" before and after the project. $15.56 \%$ of the students answered "Disagree" before the project while no student answered "Disagree" after the project. $40.00 \%$ of the students answered "Neither agree nor disagree" before the project while $11.11 \%$ answered "Neither agree nor disagree" after the project. $35.56 \%$ of the students answered "Agree" before the project while $46.67 \%$ of the students answered "Agree" after the project. $8.89 \%$ of the students answered "Strongly agree" before the project while $42.22 \%$ of the students answered "Strongly agree" after the project. The result of t-test is 0.000 which shows that there is a significant difference between the beginning and the end of the teaching intervention with the use of the method project.

To the item "Arts is useful for every person" $6.67 \%$ of the students answered "Strongly disagree" before the project while $11.11 \%$ of the students answered "Strongly disagree" after the project. $51.11 \%$ of the students answered "Disagree" before the project while 13.33\% answered "Disagree" after the project. $35.56 \%$ of the students answered "Neither agree nor disagree" before the project while $28.89 \%$ answered "Neither agree nor disagree" after the project. $4.44 \%$ of the students answered "Agree" before the project while $28.89 \%$ of the students answered "Agree" after the project. $2.22 \%$ of the students answered "Strongly agree" before the project while $17.78 \%$ of the students answered "Strongly agree" after the project. The result of t-test is 0.000 which shows that there is a significant difference between the beginning and the end of the teaching intervention with the use of the method project.

To the item "I make many mistakes in the subject of Arts" $20.00 \%$ of the students answered "Strongly disagree" before the project while $51.11 \%$ of the students answered "Strongly disagree" after the project. $42.22 \%$ of the students answered "Disagree" before the project while 26.67\% answered "Disagree" after the project. 22.22\% of the students answered "Neither agree nor disagree" before the project while $17.78 \%$ answered "Neither agree nor disagree" after the project. $11.11 \%$ of the students answered "Agree" before the project while $4.44 \%$ of the students answered "Agree" after the project. $4.44 \%$ of the students answered "Strongly agree" before the project while no student answered "Strongly agree" after the project. The result of t-test is 0.000 which shows that there is a significant difference between the beginning and the end of the teaching intervention with the use of the method project.

To the item "The subject of Arts is useful because it helps me understand other subjects" $55.56 \%$ of the students answered "Strongly disagree" before the project while $6.67 \%$ of the students answered "Strongly disagree" after the project. $26.67 \%$ of the students answered "Disagree" before the project while $24.44 \%$ answered "Disagree" after the project. $13.33 \%$ of the students answered "Neither agree nor disagree" before the project while $22.22 \%$ answered "Neither agree nor disagree" after the project. 2.22\% of the students answered "Agree" before the project while $31.11 \%$ of the students answered "Agree" after the project. $2.22 \%$ of the students answered "Strongly agree" before the project while $15.56 \%$ of the students answered "Strongly agree" after the project. The result of t-test is 0.000 which shows that there is a significant difference between the beginning and the end of the teaching intervention with the use of the method project.

To the item "It is difficult for me to connect the subjects of Arts with other subjects" $8.89 \%$ of the students answered "Strongly disagree" before the project while $22.22 \%$ of the students answered "Strongly disagree" after the project. $26.67 \%$ of the students answered "Disagree" before the project while $53.33 \%$ answered "Disagree" after the project. $33.33 \%$ of the students answered "Neither agree nor disagree" before the project while $15.56 \%$ answered "Neither agree nor disagree" after the project. $22.22 \%$ of the students answered "Agree" before the project while $4.44 \%$ of the students answered "Agree" after the project. $8.89 \%$ of the students answered "Strongly agree" before the project while $4.44 \%$ of the students answered "Strongly agree" after the project. The result of t-test is 0.000 which shows that there is a significant difference between the beginning and the end of the teaching intervention with the use of the method project.

To the item "I am interested in the subject of Arts" $11.11 \%$ of the students answered "Strongly disagree" before the project while $6.67 \%$ of the students answered "Strongly disagree" after the project. $37.78 \%$ of the students answered "Disagree" before the project while $8.89 \%$ answered "Disagree" after the project. $33.33 \%$ of the students answered "Neither agree nor disagree" before the project while $20.00 \%$ answered "Neither agree nor disagree" after the project. $8.89 \%$ of the students answered "Agree" before the project while $20.00 \%$ of the students answered "Agree" after the project. $8.89 \%$ of the students answered "Strongly agree" before the project while $44.44 \%$ of the students answered "Strongly agree" after the project. The result of t-test is 0.000 which shows that there is a significant difference between the beginning and the end of the teaching intervention with the use of the method project. 
To the item "I will try to use what I learn in the subject of Arts in my life outside of school" $24.44 \%$ of the students answered "Strongly disagree" before the project while $4.44 \%$ of the students answered "Strongly disagree" after the project. $48.89 \%$ of the students answered "Disagree" before the project while $17.78 \%$ answered "Disagree" after the project. $20.00 \%$ of the students answered "Neither agree nor disagree" before the project while $28.89 \%$ answered "Neither agree nor disagree" after the project. $2.22 \%$ of the students answered "Agree" before the project while $33.33 \%$ of the students answered "Agree" after the project. $4.44 \%$ of the students answered "Strongly agree" before the project while $15.56 \%$ of the students answered "Strongly agree" after the project. The result of t-test is 0.000 which shows that there is a significant difference between the beginning and the end of the teaching intervention with the use of the method project.

To the item "I like to deal with issues related to Art" $20.00 \%$ of the students answered "Strongly disagree" before the project while $6.67 \%$ of the students answered "Strongly disagree" after the project. $37.78 \%$ of the students answered "Disagree" before the project while $11.11 \%$ answered "Disagree" after the project. $31.11 \%$ of the students answered "Neither agree nor disagree" before the project while $17.78 \%$ answered "Neither agree nor disagree" after the project. $11.11 \%$ of the students answered "Agree" before the project while $33.33 \%$ of the students answered "Agree" after the project. No student answered "Strongly agree" before the project while 31.11 of the students answered "Strongly agree" after the project. The result of $t$-test is 0.000 which shows that there is a significant difference between the beginning and the end of the teaching intervention with the use of the method project.

To the item "I want to learn to create artistic works" $33.33 \%$ of the students answered "Strongly disagree" before the project while $2.22 \%$ of the students answered "Strongly disagree" after the project. $33.33 \%$ of the students answered "Disagree" before the project while $20.00 \%$ answered "Disagree" after the project. $17.78 \%$ of the students answered "Neither agree nor disagree" before the project while $22.22 \%$ answered "Neither agree nor disagree" after the project. $11.11 \%$ of the students answered "Agree" before the project while $37.78 \%$ of the students answered "Agree" after the project. $4.44 \%$ of the students answered "Strongly agree" before the project while $17.78 \%$ of the students answered "Strongly agree" after the project. The result of t-test is 0.000 which shows that there is a significant difference between the beginning and the end of the teaching intervention with the use of the method project.

To the item "Arts will be useful in my profession" $64.44 \%$ of the students answered "Strongly disagree" before the project while $8.89 \%$ of the students answered "Strongly disagree" after the project. $28.89 \%$ of the students answered "Disagree" before the project while $15.56 \%$ answered "Disagree" after the project. $4.44 \%$ of the students answered "Neither agree nor disagree" before the project while $35.56 \%$ answered "Neither agree nor disagree" after the project. $2.22 \%$ of the students answered "Agree" before the project while $35.56 \%$ of the students answered "Agree" after the project. No student answered "Strongly agree" before the project while 4.44\% of the students answered "Strongly agree" after the project. The result of t-test is 0.000 which shows that there is a significant difference between the beginning and the end of the teaching intervention with the use of the method project.

To the item "I want to participate in artistic activities" $40.00 \%$ of the students answered "Strongly disagree" before the project while $8.89 \%$ of the students answered "Strongly disagree" after the project. $28.89 \%$ of the students answered "Disagree" before the project while 20.00\% answered "Disagree" after the project. $17.78 \%$ of the students answered "Neither agree nor disagree" before the project while $35.56 \%$ answered "Neither agree nor disagree" after the project. $8.89 \%$ of the students answered "Agree" before the project while $24.44 \%$ of the students answered "Agree" after the project. $4.44 \%$ of the students answered "Strongly agree" before the project while 11.11 of the students answered "Strongly agree" after the project. The result of t-test is 0.000 which shows that there is a significant difference between the beginning and the end of the teaching intervention with the use of the method project.

\section{Discussion}

During the first quarter of the school year 2014-2015 a teaching intervention in the subject of Arts with the use of the project method was realized in Rhodes, Greece. The subject of the project theme was "the acropolis of Filerimos". High School students worked on activities that go beyond the typical classroom practice, faced the interdisciplinary view of learning, came out of school, moved to the acropolis of Filerimos in the city of Ialysos, visited cultural sites, discussed, researched, designed, wrote reports, worked with new technologies, etc. (Gallagher, 1964; Guilford, 1952).

A questionnaire was given to the students before and after the teaching intervention and the results fully justified the research question posed initially: "Acquiring positive attitudes of students towards the subject of Arts 
through the use of project method" (Osborn, 1953; Perkins, 1993).

The teaching intervention using the method project that was realized in Arts in the frame of this study satisfies the objectives of the subject. The research showed that the students' views and attitudes towards the Arts improved significantly (Murno, 1957; Nielsen, 1999).

The research also showed that the acceptance of the combination of the subject of Arts with activities related to cultural heritage was great as well as the recognition of the interdisciplinary nature of Arts and its connection with other subjects during the teaching process (Schroeder, 1993).

\section{References}

Gallagher, J. (1964). Productive Thinking. Review of child development Research, 1, 359.

Guilford, J. P. (1952). Some recent findings on thinking abilities and their implications. International Bulletin, $3(3), 61$.

Isaksen, S., Dorval, B., \& Treffinger, D. (1994). Creative approaches to problem solving (p. 6). Buffalo: Publishing Kendall, Hunt Company.

Johnson, D. W., \& Johnson, R. T. (1994). Learning Together and Alone: Cooperative, Competitive, and Individualistic Learning (4th ed.). Needham Heights, MA: Allyn and Bacon.

Kampouropoulou, M., Athanasiadis, I., \& Stefos, E. (2012). Greek high school students'attitudes towards the subject of Technology (pp. 3518-3523). In the Proceedings of the 6th International Technology, Education and Development Conference (INTED2012), the International Academy of Technology, Education and Development (IATED). Valencia, Spain.

Kampouropoulou, M., Stefos, E., \& Panagiotopoulou, P. (2011). The use of web tools in Art Teaching. A cross-thematic approach in the High school about the knights' monuments of Rhodes (pp. 301-310). In the Proceedings of the 2nd Panhellenic Conference "Integration and use of the Information and Communication Technologies in the Teaching Process". Patra.

Kampouropoulou, M., Stefos, E., Efstathiou, I., \& Syntihakis, H. (2014). Virtual Art Museum and Descriptive Statistics. A Teaching Proposal. In M. Chatzinikolas, K. Tzirtzipi, \& K. Vasilakis (Eds.), In the paths of educational activities (pp. 105-113). Rhodes: Evdimos Editions.

Murno, T. (1957). Art Education: Its Philosophy and Psychology. New York: Wiley.

Nielsen, H. S. (1999). The use of source material in the teaching and learning of history in upper secondary education in Denmark. Bulletin, 11.

Oliver, M. (2000). An Introduction to the Evaluation of Learning Technology. Educational Technology \& Society, $3(4), 20-30$.

Osborn, A. F. (1953). Applied imagination: Principles and procedures of creative thinking. New York: Scriber.

Perkins, D. (1993). Teaching for understanding. The Professional Journal of the American Federation of Teachers, 17(3), 28-35.

Schroeder, C. (1993). New students-New learning styles. Change Magazine, 25(5), 21-26. http://dx.doi.org/10.1080/00091383.1993.9939900

Scott, J. (1990). A Matter of Record: Documentary Sources in Social Research. Cambridge: Polity.

Starko, A. J. (1995). Creativity in the classroom: Schools of curious delight (p. 36). New York: Longman.

Stefanou, E., Athanasiadis, I., \& Stefos, E. (2013). Monuments of History and Heritage: Interpretation and Meaning of the Material Remains of the Past by Greek Educators. Pedagogical Currents, University of the Aegean, 6-7, 17.

Stefos, E., Athanasiadis I., Gialamas, B., \& Tsolakidis, C. (2011). The Use of New Technologies and the Project Method in Teaching Statistics: A Case Study in Higher Education. HMS i JME, 3, 84-100.

Torrance, E. P. (1962). Guiding creative talent. Englewood Clifts, New York: Prentice Hall. http://dx.doi.org/10.1037/13134-000 


\section{Copyrights}

Copyright for this article is retained by the author(s), with first publication rights granted to the journal.

This is an open-access article distributed under the terms and conditions of the Creative Commons Attribution license (http://creativecommons.org/licenses/by/3.0/). 